\title{
GEORGE GEORGIEVICH PORTNOV (1939-2015)
}

\section{Editorial Board}

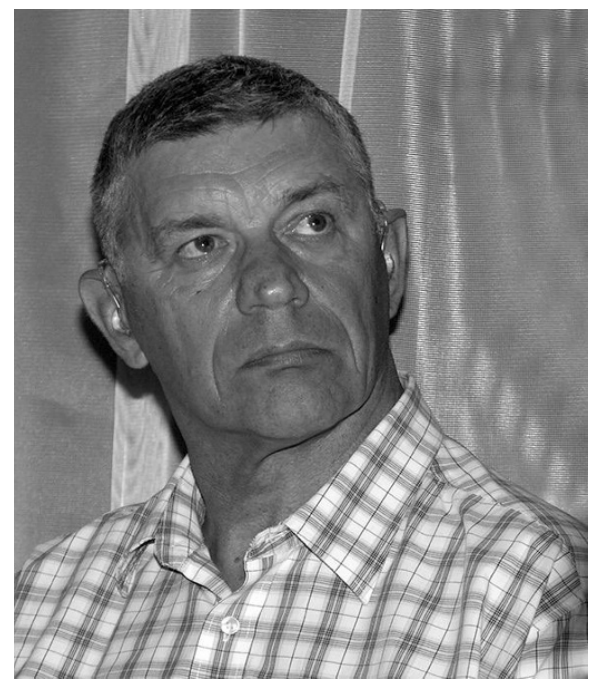

With a deep sorrow, we have to announce that professor Georgii Georgievich Portnov, the leading researcher of the Institute of Polymer Mechanics, Dr. habil., passed away on January, 30, 2015 after a heavy disease.

G. G. Portnov began his research activity after graduation from the Mechanical Faculty of Riga Polytechnic Institute in 1961. Since 1963, his scientific life was connected with the Institute of Polymer Mechanics, where he had worked for more than 50 years in the Laboratory of Strength of Composite Structures.

In 1967, he defended his candidate dissertation, and in 1985, became Doctor of Science. In these dissertations, G. G. Portnov created a scientific bases of the engineering mechanics of wound thick-walled structures made of composite materials, including the methods of control of initial technological stresses. A great cycle of his investigations was dedicated to the problems on designing and calculation of composite high-energy flywheel energy storage units. In the last years, his scientific interests were connected with the development of efficient anchor systems for the transfer of mechanical loads in composite structures. His theoretical elaborations G. G. Portnov always carried out in association with problems of their practical engineering application.

G. G. Portnov was a supervisor in preparation and defense of 13 candidate dissertations. He is author of more than 100 scientific papers, including three monographs and two chapters in International handbooks, and of 12 patents.

Georgii Georgievich Portnov was the member of the Editorial Council of our journal, and with great sadness, the Editorial Board of the journal of "Mechanics of Composite Materials" got to know about his passing away. His opinion was always reasonable and just. He was a great patriot of our Institute.

George Georgievich Portnov will remain in our memory as a remarkable colleague, a responsive person, and a talented scientist of the Institute of Polymer Mechanics, the Institute his whole scientific life was dedicated to. And it may be symbolic that Georgii has left us now, when the Institute experiences rather hard times.

Translated from Mekhanika Kompozitnykh Materialov, Vol. 51, No. 3, p. 571 , May-June, 2015. 